\title{
Traditional Latvian herbal medicinal plants used to treat parasite infections of small ruminants: A review
}

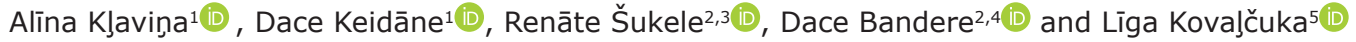

1. Institute of Food and Environmental Hygiene, Faculty of Veterinary Medicine, Latvia University of Life Sciences and Technologies, LV-3004, Jelgava, Latvia; 2. Department of Pharmaceutical Chemistry, Faculty of Pharmacy, Rīga Stradinš University, LV-1007 Riga, Latvia; 3. Department of Pharmacy, Red Cross Medical College of Rīga Stradinš University, LV-1007 Riga, Latvia; 4. Baltic Biomaterials Centre of Excellence, Headquarters at Riga Technical University, Dzirciema Street 16, Riga, LV1007, Latvia; 5. Clinical Institute, Faculty of Veterinary Medicine, Latvia University of Life Sciences and Technologies, LV-3004, Jelgava, Latvia.

Corresponding author: Liga Kovalčuka, email: kovalcuka@gmail.com

Co-authors: AK: alina.visocka@llu.Iv, DK: dace.keidane@llu.Iv, RŠ: rsukele@gmail.com, DB: Dace.Bandere@rsu.Iv Received: 04-02-2021, Accepted: 27-04-2021, Published online: 17-06-2021

doi: www.doi.org/10.14202/vetworld.2021.1548-1558 How to cite this article: Klavina A, Keidāne $D$, Šukele R, Bandere D, Kovalčuka L (2021) Traditional Latvian herbal medicinal plants used to treat parasite infections of small ruminants: A review, Veterinary World, 14(6): 1548-1558.

\begin{abstract}
Numerous treatment agents offering prophylaxis against livestock parasites are commercially available. However, because of increasing antiparasitic drug resistance, the increased popularity of environmentally friendly lifestyle choices, and organic farming, there is more demand for new alternatives to livestock anthelmintic control strategies and medications. It is important to develop antiparasitics that are safe, effective, inexpensive, and environmentally safe. Local, traditional herbal plants such as tansy, mugwort, wormwood, and heather may serve as treatments for intestinal parasites of sheep. This overview provides knowledge of traditional Latvian plants with antiparasitic activities to establish a database for further research to develop new herbal antiparasitic drugs.
\end{abstract}

Keywords: antiparasitic, gastrointestinal nematodes, heather, mugwort, polyphenols, sheep, tansy, wormwood.

\section{Introduction}

Small ruminants, particularly sheep and goats, occupy an important ecological and economical niche in Latvian agriculture. Among 1.9 million inhabitants, there are 120,726 sheep and 3467 official sheep farms registered [1]. Sheep are kept in Latvia for numerous reasons. Most important, ruminants convert poor foodstuffs into important products such as milk, meat, and wool for human consumption [2]. Moreover, poor, overgrown, and wet fields serve as reservoirs for parasites of sheep such as Fasciola hepatica, Paramphistomum spp., Heamonchus contortus, Trichostrongylus axei, Trichostrongylus colubriformis, Trichuris ovis, and Monezia expansa [3] that cause widespread infections of sheep [4]. Diverse endo- or ectoparasites affect sheep; and their adverse effects on health, production, and welfare are robustly documented [5,6]. For example, Trichostrongylidae infection is among the major challenges to ovine health management because of deleterious disease-caused effects and emerging antiparasitic drug resistance to available manufactured veterinary anthelmintics worldwide [4,7].

Numerous prophylactic agents are commercially available. However, because of increasing resistance

Copyright: Klavina, et al. Open Access. This article is distributed under the terms of the Creative Commons Attribution 4.0 International License (http://creativecommons.org/licenses/ by/4.0/), which permits unrestricted use, distribution, and reproduction in any medium, provided you give appropriate credit to the original author(s) and the source, provide a link to the Creative Commons license, and indicate if changes were made. The Creative Commons Public Domain Dedication waiver (http:// creativecommons.org/publicdomain/zero/1.0/) applies to the data made available in this article, unless otherwise stated. to anthelmintics and increased popularity of environmentally friendly lifestyle choices and organic farming, new alternatives to current parasite control and treatment strategies are urgently required. Therefore, medicinal products that are safe, effective, inexpensive, and safe for the environment must be identified. For example, newer treatment strategies employ locally harvested herbal plants. This modern branch of traditional ethnoveterinary pharmacology, similar to phytotherapy, is based on knowledge passed down through generations. This subdiscipline of pharmacology lost popularity during the intensive industrial pharmacological era; however, it is now regaining interest. Unfortunately, we lack compelling scientific evidence supporting the beneficial effects of herbal medications.

Here, we aimed to review the past and present status of traditional herbal medicinal products historically used in Latvian traditional (folk) medicine for their anticipated antiparasitic effects in comparison to the available scientific literature, particularly related to sheep. This overview attempts to consolidate scientific knowledge of traditional Latvian plants with antiparasitic activities to assist future research.

\section{Methods}

We searched Scopus, Web of Science, EBSCO, and PubMed for relevant articles published between January 1980 and September 2020. Other publications were sourced from references in individual articles. Relevant articles were selected after reading their titles and abstracts, and full text was acquired if this 
information was insufficient to exclude the study. Five herbal plants were chosen for review.

\section{Parasitic Diseases of Sheep}

Parasitic diseases of grazing production animals such as sheep and goats, commonly cause major loss of body weight and productivity leading to increased mortality, which represent important animal welfare concerns worldwide $[8,9]$. For example, mortalities of intensively stocked, untreated lambs during their $1^{\text {st }}$ year of life range between $10 \%$ and $45 \%$ [10]. Economic losses are caused by mortality, veterinary services, drug expenses, and production losses. Parasitic gastroenteritis is a prevalent parasitic disease of ruminants in all Baltic states and Europe [9,11-14].

Evidence indicates that Trichostrongylidae family nematodes are the most pathogenic main species of the genera Haemonchus and Ostertagia. H. contortus and $O$. circumcincta, which are the most frequently identified pathogens of the ovine gastrointestinal tract, cause numerous digestive disorders $[15,16]$. Both species employ a direct life cycle in which adults deposit eggs, which are excreted in the host's feces into the environment. Ostertagia spp. and Haemonchus spp. females lay between 100-200 and 5000-15,000 eggs/day, respectively. Environmental temperature and humidity are important for the survival of eggs and the development of mature parasites. Further, Trichostrongylidae eggs survive colder climates $[16,17]$. After hatching, larvae undergo subsequent molts into infectious third-stage (L3) larvae that migrate horizontally (terrestrially) or vertically on grass stalks. Moreover, horizontal migration typically ranges from $5 \mathrm{~m}$ to $10 \mathrm{~m}[9,15,18]$.

Among larval stages (L1, L2, and L3), L3 larvae are the most resistant in the environment. For example, evidence indicates that L3 larvae survive for $>6$ weeks in soil, although gastrointestinal nematodes larvae possibly survive for 1 year under favorable environmental conditions $[15,17,19]$. Sheep are infected by ingestion of L3 larvae, which molt twice in the abomasum molt before maturation. Under favorable conditions, the lifecycle past 3 weeks. When animals ingest numerous L3 larvae at the end of summer, their further development may arrest for $\leq 6$ months at L4 Adult nematodes are thin roundworms, ranging in length from $1.0 \mathrm{~cm}$ to $2.0 \mathrm{~cm}$. $H$. contortus is usually red, while Ostertagia circumcincta is brown [15].

During the development of $O$. circumcincta larvae, the number of mast cells in the abomasum decreases, although the number of nonacid producing glands increases. Initially, changes occur only in glands where larvae develop. When the larvae reach 1.3-8 $\mathrm{mm}$, the glands stretch, and the adjacent glands become affected, causing the mucous membrane of the abomasum to thicken and become hyperplastic. Sheep with a very high nematode load may develop gastric ulcers, which are accompanied by a predicted increase in the $\mathrm{pH}$ of the abomasum [15,20-23].
$H$. contortus feeds through sucking blood from the abomasum mucosa, which induces local inflammation of the mucosa at the parasite's attachment site. An adult nematode can ingest $0.05 \mu 1$ of blood per day, leading to anemia of the host. Further, a load of $>10,000$ adult nematodes in a lamb potentially causes fatal blood loss, and sheep may suffer from the toxic effects of metabolic end-products derived from larval and adult parasites [22,23].

In sheep, the main clinical signs of parasitic gastroenteritis are anemia, delayed growth, anorexia, and weight loss. Hypoalbuminemia frequently occurs in highly infested animals, contributing to edema of the lower jaw and diarrhea [9]. Abnormal gastric secretion occurs in highly infested sheep, which is characterized by increased levels of the secreted gastric hormone gastrin and the proenzyme pepsinogen (a proenzyme) in the systemic circulation [15]. Together, growth retardation, weight loss, clinical illness, veterinary services, treatment expenses, and lost production and income cause significant economic losses.

\section{Worm Control Practices in Ruminants}

Numerous types of worm control practices are employed worldwide. For example, a diet supplemented with high amounts of protein, amino acids such as methionine and leucine, and rumen-protected protein boost immunity, inhibit parasite proliferation, maintain agricultural and commercial production, and reduce fecal egg counts during infection [24-26]. The commercial vaccine "Barbervax," which was released in Australia, achieves efficacy in field trials; however, the production of its recombinant subunits was unsuccessful $[27,28]$. Copper oxide wire particles initially used as a mineral supplement are effective and safe for treating $H$. contortus infection of weaning lambs $[29,30]$. In Latvia and Baltic states, pharmaceutical deworming is the most frequently used management strategy.

Macrocyclic lactones, which are the main drugs currently used in veterinary practice to treat gastrointestinal helminths, include avermectins and milbemycins; benzimidazoles, including albendazole, febantel, and fenbendazole; tetrahydropyrimidines, including pyrantel and morantel; and cyclic depsipeptides, including emodepside, piperazines, and praziquantel [31]. The Latvian Food and Veterinary service drug register lists 658 prescription-only veterinary antiparasitic formulations, among which 21 are licensed as anthelmintic medications for treating sheep as follows: Ivermectin, levamisole, albendazole, closantel, and monepantel [32]. Ivermectin (a macrocyclic lactone), albendazole (a benzimidazole), or both are most frequently used by Latvian sheep farms.

Unfortunately, intensive use or overuse of anthelmintics, insufficient dosing, repeated treatment, and incorrect drug administration routes contribute to the development of selective pressure on the parasites. The increasing resistance of pathogenic gastrointestinal 
parasites to available anthelmintics is an important veterinary and economic concern of sheep and goat farms in numerous European countries [33-40], including Latvia's neighbor Lithuania $[11,35]$.

The rates of anthelmintic resistance in the lower temperature zones such as the Nordic countries, and possibly the Baltic states, are generally lower compared with those in warmer climates $[6,41,42]$. Unfortunately, anthelmintic resistance is directed against most classes of commonly used broad-spectrum anthelmintics. Resistance of gastrointestinal nematodes against benzimidazoles, imidazothiazoles, tetrahydropyridines, and macrocyclic lactones occurs in sheep [6,14,42-44]. A study using fecal egg-count reduction tests found that anthelmintic resistance in the Baltic state is $27.8 \%$ in Lithuanian sheep flocks [11,35]. Macrocyclic lactones, benzimidazoles, and levamisole were used to treat gastrointestinal nematodes in $68.6 \%, 27.5 \%$, and $3.9 \%$ of cases, respectively. A pilot study conducted in Estonia detected resistance against benzimidazoles and macrocyclic lactones [45]. Unfortunately, data are not available regarding anthelmintic resistance in Latvian sheep farms, which inspired the present investigation.

\section{Plants Used in Traditional (Folk) Medicine in Latvia}

Latvian culture retains a strong folk memory that frequently contributes to an understanding of veterinary pathogens. For example, knowledge of diverse home remedies and the medicinal properties of plants is historically orally communicated through families, communities, and between generations. Recent research shows the importance of such folk traditions. For example, a summary of local plants used in Latvia during the $19^{\text {th }}$ Century was obtained from the Archives of Latvian Folklore. The collection comprises songs, poems, and books with 1900 records on the use of medicinal plants. According to these records, 211 plant genera representing 71 families were used by indigenous Latvian people during the $19^{\text {th }}$ Century. Possible therapeutic uses of local plants and their components, including individual dosages and descriptions of routes of administration, are described in this research [46,47].

Although human medicine commonly employs plants, very little data are available regarding ethnoveterinary medicine in Latvia. For example, a study conducted in Europe did not include reports of herbal medicine applied to animals [48]. The geographical location of Latvia and its consequently temperate climate supports and promotes an abundance of diverse flora. An impressive variety of local plants is, therefore, available for use in herbal medicine, particularly in its veterinary subdiscipline.

Herbal drugs were extensively used worldwide as anthelmintics before the introduction of modern broad-spectrum pharmacological agents [49]. Further, certain modern anthelmintics are derived from naturally occurring plants or their synthetic ana$\operatorname{logs}$ [50]. Research performed to develop effective drugs from herbal compounds [51-53] identified drugs subsequently shown to be economically efficient, with minimal adverse effects [52].

Here, we reviewed more than 128 scientific articles on ethnoveterinary medicinal plants used in countries that share Latvia's representative flora. We selected and summarized plants with suspected antiparasitic/anthelmintic properties naturally occurring in Latvia. We identified 82 plant species and 32 plant families that met the inclusion criteria. The most widely represented plant family was Asteraceae - 18 species, followed by Apiaceae - 7, Lamiaceae - 6, Fabaceae - 4, Ranunculaceae - 4, and Poaceae and Salicaceae -3 representatives each. Other families included one or two representatives. The Asteraceae family is the most common medicinal plant found outside of Latvia, with a similar distribution of families [48].

Despite a large number of plants with medicinal properties for human and veterinary medicine, these properties are greatly affected by the chemical composition of each plant, particularly by secondary plant metabolites. Such compositions may vary depending on climate, country, soil properties, season, and other environmental conditions. The fact that a plant has anthelmintic activity in one part of the word does not mean that it will be the same in another. The chemical composition and properties of a plant are affected by harvesting, storage, the components of a plant, and the type. Most frequently, the entire plant is used, or various combinations of plant extracts [54]. Further, it is important to choose the appropriate extraction solvent according to the solubility's of secondary metabolites of a target plant. Water and methanol are most frequently used solvents. Some believe ethanolic extracts are better, because it is easier for them to enter the parasite's body through transauricular absorption [3].

Two broad study types are used to determine a plant's properties - in vitro and in vivo. Each study has advantages and disadvantages. In vitro studies are less expensive, simultaneously analyze multiple plants, and are reproducible [55]. Further, in vitro studies allow the investigation of specific parasites and their lifecycles. The egg hatch (eggs), larval development (larvae), and larval motility (adults) tests are typically performed. In vivo studies are lengthier, only investigate one plant at a time, and are difficult to replicate. An in vitro study should initially be performed, and the plants that exhibit the best effect should be selected for subsequent in vivo studies. Often, the in vitro and in vivo results for the same plant differ. Further, the outcomes can be influenced by an animal's internal factors, and plant species exert clinical effects that vary depending on the digestive system of the host, for example, ruminant versus a monogastric animal [54-56]. 
Thirty plants (including trees and shrubs) with anthelmintic activity toward ruminant endoparasites are listed in Table-1 [57-71]. Four plants were studied and are discussed in detail. The tansy, wormwood, and mugwort are widely used in herbal medicine, and heather (Calluna vulgaris) is described less frequently. Research into newer natural substances for medicinal use is trending [72]. Secondary metabolites of plants such as alkaloids, steroids, phenolics, tannins, flavonoids, resins, and fatty acids, have important impacts on health and exert numerous medicinal effects. Thousands of extracted and separated natural compounds serve as pharmaceuticals. Many conventional drugs such as quinine, artemisinin, and morphine are derived from natural sources [73,74].

Polyphenolic compounds, particularly flavonoids ( $>4000$ structurally distinct molecules), are intensely studied secondary metabolites. The basic aglycone moiety comprises two benzene rings linked through a heterocyclic pyran ring. Flavonoids, which are often variably hydroxylated at various positions, are classified as flavones (luteolin, apigenin), flavonols (quercetin and kaempferol), flavanones (hesperetin), isoflavones (genistein), flavan-3-ols (catechin and epicatechin), and others [75]. The benefits of quercetin, catechin, kaempferol, resveratrol, apigenin, and luteolin are robustly documented. Flavonoids possess antioxidant, anti-inflammatory, antiseptic, antibacterial, and antiparasitic activities that protect against numerous chronic diseases and delay aging [74,76,77].

Polyphenolic tannins, which are of considerable medical interest as well, possess an astringent taste and are used in the food and pharmaceutical industries. Tannins are classified as hydrolyzable (gallic acid and ellagic acid) or condensed (proanthocyanidins). The medicinal properties of tannins are as follows: Anthelmintic, antibacterial, antidiarrheic, antiviral, antihepatotoxic, antihypertensive, anti-ulcer, anticancer, and antioxidant (condensed tannins only) $[43,78,79]$.

Alkaloids are heterocyclic nitrogen-containing compounds, representing an undoubtedly important group of secondary metabolites. Approximately 20,000 alkaloids have been isolated, mainly from plants, but occur as well in microorganisms, marine organisms, and terrestrial animals. Alkaloids are classified according to their molecular backbones or according to their botanical origins. The most important functional groups include indole alkaloids, isoquinoline alkaloids, tropane alkaloids, steroidal alkaloids, pyridine, and pyrrolizidine alkaloids [80]. Pharmaceuticals derived from natural alkaloids include commonly used analgesic and cardiovascular agents, chemotherapeutic and antimalarial agents, centrally acting sedatives and stimulants, smooth muscle relaxants, and others. Important examples include atropine, cysteine, scopolamine, cocaine, quinine, morphine, codeine, ephedrine, reserpine, ergotamine, vinblastine, vincristine, and caffeine [76,79,81-83].
Several clinical trials of extensively studied essential oils are in progress. These compounds comprise mixtures of volatile, complex hydroalcoholic oil-soluble compounds, which are used as cosmetics and pharmaceuticals. Their structures are as follows: Acyclic and monocyclic monoterpenes (1,8-cineole, alfa pinene, camphor, linalool, nerol, and geraniol), bicyclic and tricyclic monoterpenes (sabinene, thujone, and tricyclene), sesquiterpenes (e-nerolidol, carvacrol methyl ether, germacrene B, and cadalene), isoprenoides, and terpenoids that include aldehydes, ethers, alcohols (carvacrol, thymol, eugenol, and borneol), and sulfur- or nitrogen-containing compounds (diallyl disulfide and indole) $[84,85]$. Mentions of essential oil plants, essential oils, and their derived single constituents appear in pharmacopoeias and traditional medicine paradigms of different cultures. These substances have been used in medicine because of their potential antimicrobial, antiparasitic, antioxidant, anti-inflammatory, and anticancer effects, as well as to treat stress, anxiety, and depression [86-88].

Tanacetum vulgare L., or tansy, is a perennial herb produced by genera of the Asteraceae family. The plant has a specific smell; and wild tansy, which is widely distributed across Latvia, is commonly mentioned in Latvian folk medicine. Tansy exerts healing effects, including anti-inflammatory, antioxidant, antibiotic, and cytotoxic effects $[88,89]$. Tanacetum balsamita L. (customary), Tanacetum parthenium (L.) Sch. Bip. (syn. Pyrethrum parthenium (L.) Sm., or feverfew are cultivated in Latvia. Despite its use as a typical folk medicine plant, there are few scientific articles or studies that focus on tansy's antiparasitic effects. For example, T. vulgare is ineffective on the eggs and larvae of $H$. contortus [90].

Tansy is rich in essential oils as revealed by gas chromatography-mass spectrometry analysis (49-55 volatile compounds). Combinations of compounds vary between samples and are affected by different growing locations and conditions. The yields of essential oils from tansy range between 0.35 and $1.90 \%$ (v/w). Commonly studied essential oil components are as follows: 1,8 cineol, alpha-pinene, beta thujone, borneol, Artemisia alcohol, camphor, caryophyllene, acetals, tanacetin, and tanacetol A, B. T. vulgare essential oil contains a high concentration of thujone ( $\alpha$ and $\beta$ ) (>50\%) [91-94].

Thujone belongs to the essential oil group of isoprenoids (monoterpene ketone). High doses of thujone cause neurotoxicity in animals, manifested as hyperactivity, tremors, and tonic seizures. Therefore, it is best to use aqueous extracts of tansy, which contain lower doses of thujone [57]. Tansy flowers are used, for example, as antioxidants, antibacterial, anthelmintics, cytotoxic drugs, and repellents [93,95-98].

Recent studies show that tansy comprises numerous polyphenols. Spectrophotometric analysis of tansy flowers reveals gentisic, caffeic, chlorogenic, p-coumaric, and ferulic acids; hyperoside, 
Table-1: Plants used for ruminants endoparasites.

\begin{tabular}{|c|c|c|c|c|c|c|}
\hline Scientific name & $\begin{array}{l}\text { English } \\
\text { name }\end{array}$ & Botanic family & Parasites type & $\begin{array}{l}\text { Used } \\
\text { parts** }\end{array}$ & Animals* & References \\
\hline Achillea millefolium L. & Yarrow & Asteraceae & $\begin{array}{l}\text { Gastrointestinal } \\
\text { nematodes }\end{array}$ & W, E & $\mathrm{S}$ & {$[58]$} \\
\hline Acorus calamus L. & Sweet - flag & Araceae & Helminths & $\mathrm{R}$ & $\mathrm{C}$ & {$[58]$} \\
\hline Alnus glutinosa L. & Alder & Betulaceae & Trematodes & Sh & $\mathrm{S}$ & [59] \\
\hline Artemisia absinthium L. & Wormwood & Asteraceae & $\begin{array}{l}\text { Nematodes } \\
\text { (Haemonchus } \\
\text { contortus, } \\
\text { Trichostrongylus } \\
\text { colubriformis, } \\
\text { Toxocara vitulorum), } \\
\text { Cestodes, } \\
\text { Protozoa (Eimeria } \\
\text { Spp.) }\end{array}$ & $A, E, W, L$ & C, S, G & {$[57,59-62,64]$} \\
\hline Artemisia campestris L. & $\begin{array}{l}\text { Field } \\
\text { wormwood }\end{array}$ & Asteraceae & $\begin{array}{l}\text { Nematodes } \\
\text { (Haemonchus } \\
\text { contortus) }\end{array}$ & $L, E$ & $\mathrm{~S}, \mathrm{G}$ & {$[69,62-64]$} \\
\hline Artemisia maritime L & $\begin{array}{l}\text { Sea } \\
\text { wormwood }\end{array}$ & Asteraceae & Nematodes & - & $\mathrm{S}$ & [62] \\
\hline Artemisia vulgaris L. & Mugwort & Asteraceae & $\begin{array}{l}\text { Nematodes } \\
\text { (Trichostrongylus } \\
\text { colubriformis) }\end{array}$ & - & $\mathrm{C}, \mathrm{S}$ & {$[62,64]$} \\
\hline Betula pubescens Ehrh. & Downy birch & Betulaceae & Helminths, Cestodas & $\mathrm{L}, \mathrm{Ba}$, sap & $\mathrm{S}$ & [59] \\
\hline Calluna vulgaris $\mathrm{L}$. & Hill/heater & Ericaceae & Trematodes & - & $\mathrm{S}$ & [59] \\
\hline Cichorium intybus L. & Chicory & Asteraceae & $\begin{array}{l}\text { Gastrointestinal } \\
\text { nematodes, } \\
\text { Lungworm }\end{array}$ & W & $C, D, G, S$ & {$[59,62,66,67]$} \\
\hline Consolida regalis Gray & $\begin{array}{l}\text { Forking } \\
\text { larkspur }\end{array}$ & Ranunculaceae & $\begin{array}{l}\text { Nematodes } \\
\text { (Trichostrongylus } \\
\text { colubriformis) }\end{array}$ & $\mathrm{F}$ & - & [64] \\
\hline Daucus carota L. & Wild carrot & Apiaceae & $\begin{array}{l}\text { Nematodes } \\
\text { (Trichostrongylus } \\
\text { colubriformis) }\end{array}$ & $\mathrm{R}$ & - & {$[63,64]$} \\
\hline Dryopteris filix-mas L. & Male - fern & Dryopteridaceae & $\begin{array}{l}\text { Nematodes } \\
\text { (Trichostrongylus } \\
\text { colubriformis), } \\
\text { Trematodes } \\
\text { (Dicrocoelium Spp., } \\
\text { Fasciola Spp.), } \\
\text { Cestodas (Moniezia } \\
\text { spp.) }\end{array}$ & $\mathrm{R}$ & $C, G, S$ & {$[59,62,64,68]$} \\
\hline Erigeron canadensis L. & $\begin{array}{l}\text { Canadian } \\
\text { fleabane }\end{array}$ & Asteraceae & $\begin{array}{l}\text { Nematodes } \\
\text { (Trichostrongylus } \\
\text { colubriformis) }\end{array}$ & A & - & [64] \\
\hline Humulus lupulus L. & Hop & Cannabaceae & $\begin{array}{l}\text { Helminths, Cestodes, } \\
\text { Trematodes }\end{array}$ & $\mathrm{W}, \mathrm{R}$ & $\mathrm{S}$ & [59] \\
\hline Iris pseudocorus L. & Yellow iris & Iridaceae & Helminths & $\mathrm{R}$ & C & [59] \\
\hline Juniperus communis $\mathrm{L}$. & Juniper & Cupressaceae & $\begin{array}{l}\text { Trematodes (liver } \\
\text { flukes) }\end{array}$ & $B, R$ & $\begin{array}{l}\mathrm{C}, \mathrm{G}, \mathrm{S} \\
\mathrm{C}\end{array}$ & {$[58,59,63]$} \\
\hline Lepidium sativum L. & $\begin{array}{l}\text { Garden } \\
\text { cress }\end{array}$ & Brassicaceae & $\begin{array}{l}\text { Helminths, } \\
\text { Trematodes }\end{array}$ & W, S & $\mathrm{S}$ & [59] \\
\hline Lotus corniculatus L. & $\begin{array}{l}\text { Bird`s - } \\
\text { foot - trefoil }\end{array}$ & Fabaceae & $\begin{array}{l}\text { Nematodes (Cooperia } \\
\text { oncophora, Ostertagia } \\
\text { ostertagi) } \\
\text { Lungworms } \\
\text { (Dictyocaulus eckerti) }\end{array}$ & $A, L, W$ & C, D & {$[62,67]$} \\
\hline Nigella sativa L. & $\begin{array}{l}\text { Garden } \\
\text { fennel } \\
\text { - flower }\end{array}$ & Ranunculaceae & $\begin{array}{l}\text { Gastrointestinal } \\
\text { nematodes, } \\
\text { Tapeworms }\end{array}$ & Ex, $S$ & S, G & {$[60,69]$} \\
\hline Pastinaca sativa L. & Wild parsnip & Apiaceae & Endoparasites & $A$ & $C, S, G$ & {$[63]$} \\
\hline Pyrus communis $\mathrm{L}$. & Pear & Rosaceae & Nematodes & B & $\mathrm{S}$ & [59] \\
\hline Quercus robur L. & $\begin{array}{l}\text { Pedunculate } \\
\text { oak }\end{array}$ & Fagaceae & Helminths & $\mathrm{N}$ & $\mathrm{C}$ & [70] \\
\hline Salix Spp. & Willow & Salicaceae & $\begin{array}{l}\text { Helminths, } \\
\text { Cestodes, } \\
\text { Trematodes }\end{array}$ & $\mathrm{Ba}, \mathrm{L}$ & $\mathrm{C}, \mathrm{S}$ & {$[59,71]$} \\
\hline Sambucus nigra L. & Elder & Caprifoliaceae & $\begin{array}{l}\text { Cestodes, } \\
\text { Trematodes }\end{array}$ & B & $\mathrm{S}$ & [59] \\
\hline
\end{tabular}


Table-1: (Continued).

\begin{tabular}{|c|c|c|c|c|c|c|}
\hline Scientific name & $\begin{array}{l}\text { English } \\
\text { name }\end{array}$ & Botanic family & Parasites type & $\begin{array}{l}\text { Used } \\
\text { parts** }\end{array}$ & Animals* & References \\
\hline Senecio vulgaris $\mathrm{L}$. & Groundsel & Asteraceae & Cestodes & $\mathrm{L}$ & C & [59] \\
\hline Symphori-carpos albus L. & Snowberry & Caprifoliaceae & Endoparasites & $\mathrm{L}$ & C, G, S & [63] \\
\hline Tanacetum vulgare L. & Tansy & Asteraceae & $\begin{array}{l}\text { Nematodes, } \\
\text { (Trichostrongylus } \\
\text { colubriformis) } \\
\text { Cestodes, Trematodes }\end{array}$ & $A, W, L, S$ & $\mathrm{~S}$ & {$[59,64]$} \\
\hline Urtica dioica L. & $\begin{array}{l}\text { Common } \\
\text { nettle }\end{array}$ & Urticaceae & $\begin{array}{l}\text { Helminths, } \\
\text { trematodes }\end{array}$ & W, S & $\mathrm{S}$ & {$[59]$} \\
\hline Valeriana officinalis L. & $\begin{array}{l}\text { Common } \\
\text { valerian }\end{array}$ & Valerianaceae & $\begin{array}{l}\text { Nematodes } \\
\text { (Trichostrongylus } \\
\text { colubriformis) }\end{array}$ & $\mathrm{R}$ & - & {$[64]$} \\
\hline
\end{tabular}

*Animals: $\mathrm{C}=$ Cattle, $\mathrm{D}=$ Deer, $\mathrm{G}=$ Goats, $\mathrm{S}=$ Sheep. $* *$ Used parts: $\mathrm{A}=$ Aerial parts, $\mathrm{B}=$ Berries, $\mathrm{Ba}=$ Bark, $\mathrm{E}=$ Extract, $\mathrm{F}=$ Flowers, $\mathrm{L}=$ Leaves, $\mathrm{N}=$ Nuts, $\mathrm{S}=$ Seeds, $\mathrm{Sh}=$ Shoots, $\mathrm{W}=$ Whole

isoquercitrin, rutin and quercitrin, patuletin, luteolin, kaempferol, and apigenin [89]. The total concentrations of phenol range from $46 \mathrm{mg}$ to $50 \mathrm{mg}$ gallic acid equivalents (GAE)/g. Polyphenolic compounds (phenolic acids) extracted from tansy possess antioxidant activities, although the antibacterial activities of its essential oil are low [99,100]. Further, methanol is the best extractant for polyphenols, compared, in descending order, with ethanol, water, isopropanol, and acetone. The yields of phenolics range from $12 \mathrm{mg}$ to $63 \mathrm{mg} \mathrm{GAE} / \mathrm{g}$ of the dried herb. Water serves as the most efficient extractant for preparing flavonoids [101].

Artemisia vulgaris L., or mugwort, is a very large (50-170 $\mathrm{cm}$ tall) herbaceous plant. Another widely distributed mugwort of the Asteraceae family grows in diverse habitats in Latvia. The plant possesses antileishmanial, antimalarial, antibacterial, antifungal, anthelmintic, and anti-inflammatory properties [102-104]. Mugwort comprises compounds with significant chemical polymorphisms and contains terpenes, a monoterpenoid, which contributes to the plant's odor, which is the basis of its insecticidal activity, therefore, employed as an insecticide $[105,106]$.

Artemisia is extensively studied, and numerous medicinal plants are derived from species of this genus. A review of different plants from this genus confirms their high concentrations of tannins and condensed tannins, which contribute to their antioxidant effects [107]. Artemisinin is a sesquiterpene lactone, which is produced by the Artemisia genus, is important for treating malaria [108]. Studies of the antibacterial effects of essential oils of Artemisia show that 1,8-cineole and alfa-thujone in the oil isolated from the aerial components of mugwort achieve good and nonselective activity against Escherichia coli, Salmonella Enteritidis, Pseudomonas aeruginosa, Klebsiella pneumonia, Staphylococcus aureus, Candida albicans, and Aspergillus niger. The diminished activity of essential oil from A. vulgaris root is likely explained by its reduced content of 1,8-cineole and thujone. A. absinthi essential oil contains a higher content of beta thujone and achieves higher antimicrobial effects, except when used to treat infections caused by $S$. aureus or E. coli. [109].

A. vulgaris is used in traditional medicine, and its herbs, leaves, shoots, roots, and essential oils are the subjects of numerous studies. GC/MS analysis revealed 24 different essential oil components [109] such as 1,8-cineole, alfa, beta thujone, camphor, borneol, beta-pinene, myrcene, and nerol $[99,109]$. The aerial components of $A$. vulgaris contain polyphenolics (flavonoids and tannins) and saponins [110]. High-performance liquid chromatography (HPLC) analysis shows that luteolin and morin are the main polyphenolics of methanol extracts of $A$. vulgaris [111], although hydroalcohol extracts, analyzed using HPLC/diode array detection, contain rutin, hydroxybenzoic acid, and caffeic acid [112].

A. absinthium L., or wormwood, which belongs to the Asteraceae family, similarly emits a specific wormwood odor, is widespread throughout Latvia; and folk medicine considers wormwood to have medicinal effects. Leaves and the aerial components of the plant are most commonly used in Europe [47,49]. Artemisia spp. found in Latvia are as follows: A. campestris L. (field wormwood), A. annua L. (annual mugwort), A. austriaca Jacq., A. maritima L. (sea wormwood), $A$. sieversiana Ehrh. ex. Willd., and A. verlotiorum Lamotte (Chinese mugwort). These rarely occur Latvia. In contrast, $A$. dracunculus L. (estragon) is the only one among these species that is cultivated as a herb and does not grow in the wild. A. abrotanum L. possesses medicinal properties.

A. absinthium serves as a source of numerous conventional and traditional medicines [113]. The most important chemical constituents in wormwood include flavonoids (santonin) and sesquiterpenes (artemisinin), which exert antiparasitic activities [105,114]. Artemisinin is a "parent drug" of antimalarial agents, and its derivatives have been used since 1980 [104]. These products are toxic to animals and induce neurotoxicity at high doses. A. absinthium essential oil contains thujone ( $\alpha$ and $\beta$ ) and exerts antimicrobial and antifungal effects [3]. A. absinthium oil possesses antispasmodic, antiseptic, antiparasitic, and 
insecticidal properties $[114,115]$. Aqueous and ethanolic extracts of $A$. absinthium are effective against gastrointestinal nematodes in sheep, particularly against $H$. contortus [57]. However, a recent study of wormwood as a dietary supplement did not detect a significant effect on lambs infected with $H$. contortus [115]. A partial antiparasitic effect was detected in ruminants infected with Eimeria spp. [57].

Studies of the chemical composition of Artemisia absinthium identified and characterized different groups and individual active components of plants and essential oils. The essential oil, in minimal amounts, is detected using macro-and microscopic tests, assessed as absinthin and resorcinol [116]. The essential oil of $A$. absinthium contains 1,8 cineol, camphor, linalool, alpha- and beta thujone, 4-terpineol, borneol, $\alpha$-cardinol, absinthin, artemetin, myrcene, and other mono- and sesquiterpenes. Its essential oil is used as an anti-ulcer drug, an anticarcinogenic agent, an analgesic, an immunomodulator, an antimalaria, an antiseptic, an antibacterial, an anthelmintics, a larvicide, and a pesticide, although it may be toxic under certain circumstances [99,113,117].

Diverse polyphenolics are found in A. absinthium. For example, wormwood possesses a total phenolic content (TPCs) of $19 \pm 0.16 \mathrm{mg} \mathrm{GAE} / \mathrm{g}$ [118]. Phenolic acids (tannic, gallic, salicylic, hemihydrate chlorogenic, caffeic, vanillic, syringic, ferulic, p-coumaric, rosmarinic, and trans-cinnamic acid) are detected in A. absinthium. The wormwood herb contains high levels of condensed tannins (proanthocyanidins), which contribute to its antioxidant activities. Flavonoid compounds include eupafolin, diosmetin, rhamnetin, apigenin as well as their glucosides luteolin, quercetin, rutin, and vitexin $[99,119]$. The concentrations $(\mathrm{mg} / \mathrm{g}$ routine equivalents) of flavonoids and flavanols in wormwood extracts are $7.96 \pm 0.76$ and $3.4 \pm 0.0$, respectively [120]. The type of extractant affects the yields of flavonoids extracted from the wormwood herb. Ethanolic extracts contain higher amounts of phenolics than aqueous or chloroform extracts [121], which should be considered when preparing wormwood extracts for medicinal use.

C. vulgaris (L.), hill or heather, is a perennial plant of the Ericaceae family that grows in nutrient-poor soils and is often found in pine forests. In Latvia, heather, which is a valuable nectar-producing plant with medicinal properties, is the only species of the genus that grows in Latvia. The main chemical components of the plant that potentially engage parasites are tannins. C. vulgaris (L.) has low nutritional value, and only goats use it as forage. When goats were fed heather, only a mild anthelmintic effect is observed. Reduced numbers of released T. colubriformis egg are found, although heather increases immunity to parasites [119]. When heather is fed to experimentally infected goats, it is associated with a reduction in the establishment of $T$. colubriformis larvae and a significant decrease in nematode egg excretion by the host [122]. The aerial components of heather have been studied during different growth stages; however, heather's medicinal properties are mainly described in traditional medicine, the plant's pharmacologic potential is a focus of current investigations.

Phenolic compounds are found in varying amounts throughout $C$. vulgaris. The highest total concentrations of phenolic compounds, tannins, flavonoids, hydroxycinnamic acids, and proanthocyanidins are detected in leaves and roots during all growth stages, except during flowering. During flowering, the highest concentrations of flavonoids, proanthocyanidins, and anthocyanins are detected in flowers. Heather herb possesses antioxidant activity, and its antibacterial effects are mediated by the leaf, stem, rhizome, and root extracts. Leaf and stem extracts inhibit the infectivities of Gram-positive and Gramnegative bacteria, and roots are active against Bacillus subtilis, and extracts of the rhizome are active against E. coli [122]. Further, combinations of the active substances and amounts differ according to the season and are higher during growth. The total tannin concentrations in heather range from $22 \mathrm{mg}$ to $36 \mathrm{mg}$ TAE$/ \mathrm{g} \mathrm{dw}$, with a higher proportion of the condensed form versus the hydrolysable form [123].

Aqueous extracts of inflorescences of heather contain carbohydrates, protein, lipids, fructose, glucose, organic acids, and fatty acids. Phenolic compounds identified in $C$. vulgaris extract are myricetin-3-O-glucoside and myricetin-O-rhamnoside. More polar extracts with more phenolics exhibit stronger antioxidant and antibacterial effects, whereas n-hexane and ethyl-acetate extracts achieve better anti-inflammatory and cytotoxic effects [124]. Liquid chromatography-mass spectrometry and ${ }^{1} \mathrm{H}$-nuclear magnetic resonance analyses of heather identified the fatty acids as follows: Linolenic (35\%), linoleic (27\%), and palmitic (21\%); a high content of fiber and carbohydrates (75\%); $\alpha$-tocopherol quercetin, kaempferol, and myricetin derivatives as well as procyanidins. The total amounts of phenolic compounds (TPCs) are higher in hydroalcoholic extracts. These extracts exert good antibacterial effects without causing adverse effects [125]. Photospectrometric analysis (FolicCiocalteu) revealed the presence of TPCs at concentrations ranging from $67.55 \mathrm{mg} \mathrm{GAE} / \mathrm{g}$ to $142.46 \mathrm{mg}$ $\mathrm{GAE} / \mathrm{g}$ and flavonoids at concentrations ranging from 42.11 RUE/g to $63.68 \mathrm{mg}$ RUE(Rutin equivalent)/g (using aluminum chloride) [125]. Another study demonstrates antioxidant properties [126]. The phenolic compound quercetin likely accounts for heather's calming effects $[127,128]$.

\section{Conclusion}

The emergence of helminths resistant to the most frequently used antihelmintic drugs requires urgent action to identify alternative methods. Herbal plants have huge potential for this purpose, as they are relatively inexpensive, safe, and effective. We, therefore, 
focused here on the typical Latvian herbal plants tansy, wormwood, mugwort, and heather as the focus of further in vitro studies to determine the effects of these plant extracts on strongyloid parasites.

\section{Authors' Contributions}

LK: Conceptualized the aim of the study, designed, supervised, and corrected the manuscript. $\mathrm{AK}, \mathrm{DK}, \mathrm{RS}, \mathrm{DB}$, and LK: Equally conceived the work with literature and drafted and reviewed the manuscript. All authors have read and approved the final manuscript.

\section{Acknowledgements}

This study was carried out in the framework of LLU (Latvia University of Life Sciences and Technologies) internal project "Antiparasitic drug resistance in Latvian sheep farms" (No. LLU P12) and with implementation of the research project "Development of herbal plant containing medical extracts with anti-parasitic effect" funded by the Latvia Ministry of Agriculture and Rural Support Service program LAD16.2 project: The support for pilot projects and the development of new products, practices, processes and technologies. The authors are grateful to Polina Skliarevitch for helpful comments on a draft manuscript.

\section{Competing Interests} interests.

The authors declare that they have no competing

\section{Publisher's Note}

Veterinary World remains neutral with regard to jurisdictional claims in published institutional affiliation

\section{References}

1. Available from: https://www.ldc.gov.lv/lv/statistika. Retrieved on 20-11-2020.

2. Abd El-Raof, Y.M., Ghanem, M.M. and Galbat, S. (2007) Cryopreservation of Rumen Protozoa Using Three Different Cryoprotectant Methods in Sheep. The Second Scientific Conference, Faculty of Veterinary Medicine Benha University Ras Sedr.

3. Tariq, K.A., Chishti, M.Z., Ahmad, F. and Shawl, A.S (2009) Anthelmintic activity of extracts of Artemisia absinthium against ovine nematodes. Vet. Parasitol., 160(1-2): 83-88.

4. Papadopoulos, E., Gallidis, E. and Ptochos, S. (2012) Anthelmintic resistance in sheep in Europe: A selected review. Vet. Parasitol., 189(1): 85-88.

5. Taylor, M.A., Coop, R.L. and Wall, R.L. (2007) Veterinary Parasitology. $3^{\text {rd }}$ ed. Blackwell, Oxford. p874.

6. Sargison, N. (2009) Sheep Flock Health. Blackwell, Oxford. p465.

7. Torres-Acosta, J.F., Mendoza-de-Gives, P., AguilarCaballero, A.J. and Cuéllar-Ordaz, J.A. (2012) Anthelmintic resistance in sheep farms: Update of the situation in the American continent. Vet. Parasitol., 189(1): 89-96.

8. Ihler, C.F. (2010) Antihelmintic resistance. An overview of the situation in the Nordic countries. Acta Vet. Scand., 52(Suppl 1): 1-24.

9. Kaplan, R.M. (2004) Validation of the Famacha eye colour chart for detecting clinical anaemia in sheep and goats on farms in the southern United States. Vet. Parasitol., 123(1-2): 105-120.

10. Vlassoff, A. and McKenna, P.B. (1994) Nematode parasites of economic importance in sheep in New Zealand. N. Z. J. Zool., 21(1): 1-8.

11. Kupčisnkas, T., Stadaliene, I., Šarkūnas, M., Riševičiene, V., Vārady, M., Hoglung, J. and Petkevičus, S. (2015) Prevalence of Antihelmintic resistance on Lithuanian sheep farms assessed by in vitro methods. Acta. Vet. Scand., 57(Dec.): 88.

12. Lassen, B., Järvis, T. and Mägi, E. (2013) Gastrointestinal parasites of sheep on Estonian islands. J. Agric. Sci., 1(10): 7-14.

13. Mickiewicz, M., Czopowicz, M., Kawecka-Grochocka, E., Moroz, A., Szaluś-Jordano, O., Várady, M., Königová, A., Spinu, M., Górski, P., Bagnicka, E. and Kaba, J. (2020) The first report of multidrug resistance in gastrointestinal nematodes in goat population in Poland. BMC Vet. Res., 16(1): 270 .

14. Martínez-Valladares, M., Martínez-Pérez, J.M., RoblesPérez, D., Cordero-Pérez, C., Famularo, M.R., FernándezPato, N., Castañón-Ordóñez, L. and Rojo-Vázquez, F.A. (2013) The present status of anthelmintic resistance in gastrointestinal nematode infections of sheep in the northwest of Spain by in vivo and in vitro techniques. Vet. Parasitol., 191(1-2): 177-181.

15. Smith, M.C. and Sherman, D.M. (1994) Goat Medicine. Lea and Febiger, Philadelphia, PA. p321-336.

16. Eckert, J., Friedhoff, K.T., Zahner, H. and Deplazes, P. (2005) Lenbruch der Parasitologie fur die Tiermedizin. Enke, Stuttgart. p575.

17. Simpson, H.V. (2000) Pathophysiology of abomasal parasitism: is the host or parasite responsible. Vet. J.,160(3): 177-191.

18. Hoste, H., Torres-Acosta, J.F., Paolini, V., AguilarCaballero, A., Etter, E., Lefrileux, Y., Chartier, C. and Broqua, C. (2005) Interactions between nutrition and gastrointestinal infections wits parasitic nematodes in goats. Small Rum. Res., 60(1): 141-151.

19. Hansen, J. and Perry, B. (1994) The epidemiology, diagnosis and control of helminth parasites of ruminants. In: International Laboratory for Research on Animal Diseases. p17-25.

20. Simpson, H.V., Lawton, D.E.B., Simcock, D.C., Reynolds, G.W. and Pomroy, W.E. (1997) Effect of adult and larval Haemonchus contortus on abomasal secretion. Int. J. Parasitol., 27(7): 825-831.

21. Wahab, A.R. and Collins, G.H. (1991) Infection of goats with Haemonchus contortus and Trichostrongylus colubriformis: Histopathology and $\mathrm{pH}$ changes. Br. Vet. J., 147(6): 569-574.

22. Perez, J., Garcia, P.M., Hernandez, S., Martinez-Moreno, A., de las Mulas, J.M. and Camara, S. (2001) Pathological and immunohistochemical study of the abomasum and abomasal lymph nodes in goats experimentally infected with Haemonchus contortus. Vet. Res., 32(5): 463-473.

23. Rahman, W.A. and Collins, G.H. (2006) Infection of goats with Haemonchus contortus and Trichostrongylus colubriformis: Histopathology and $\mathrm{pH}$ changes. Br. Vet. J., 147(6): 569-575.

24. Cériac, S., Archimède, H., Feuillet, D., Felicite, Y., Giorgi, M. and Bambou, J.C. (2019) Supplementation with rumen-protected proteins induces resistance to Haemonchus contortus in goats. Sci. Rep., 9(Feb.): 1237.

25. Sakkas, P., Jones, L.A., Houdijk, J.G., Athanasiadou, S., Knox, D.P. and Kyriazakis, I. (2013) Leucine and methionine deficiency impairs immunity to gastrointestinal parasites during lactation. Br. J. Nutr., 109(2): 273-282.

26. Rocha, R., Bricarello, P., Silva, M., Houdijk, J., Almeida, F., Cardia, D. and Amarante, A.F.T. (2011) Influence of protein supplementation during late pregnancy and lactation 
on the resistance of Santa Ines and Ile de France ewes to Haemonchus contortus. Vet. Parasitol., 181(2-4): 229-238.

27. Besier, B., Kahn, L., Dobson, R. and Smith, D. (2015) Barbervax ${ }^{\circledR}$ Anew Strategy for Haemonchus Management. Proceedings of the Australian Veterinary Association (AVA) Annual Conferences, Pan Pacific (NZVA and AVA) Veterinary Conference, Combined Proceedings, Brisbane. p168-174.

28. Nisbet, A., Meeusen, E., González, J. and Piedrafita, D. (2016) Immunity to Haemonchus contortus and vaccine development. Adv. Parasitol., 93: 353-396.

29. Schweizer, N.M., Foster, D.M., Knox, W.B., Sylvester, H.J. and Anderson, K.L. (2016) Single vs. double dose of copper oxide wire particles (COWP) for treatment of anthelmintic resistant Haemonchus contortus in weanling lambs. Vet. Parasitol., 229(Oct): 68-72.

30. Fetene, A. and Amante, M. (2019) Alternative to synthetic anthelminthic to prevent and control gastrointestinal parasite in sheep and goat. Am. Eur. J. Sci. Res., 14(1): 6-14.

31. Langston, C. and Varela-Strokes, A.S. (2019) Pharmacotherapy of parasitic disease. In: Katrina, L., Langston, C., editors. Pharmacotherapeutics for Veterinary Dispensing. W.B. Saunders Company, Philadelphia, PA. p127-140.

32. Available from: https://www.pvd.gov.lv/partikas-un-veterinarais-dienests/statiskas-lapas/veterinara-uzraudziba/veterinaras-zales?nid=2246\#jump. Retrieved on 20-11-2020.

33. Cernanská, D., Várady, M., Cudeková, P. and Corba, J. (2008) Worm control practices on sheep farms in the Slovak Republic. Vet. Parasitol., 154(3-4): 270-276.

34. Várady, M., Papadopoulos, E., Dolinská, M. and Königová, A. (2011) Anthelmintic resistance in parasites of small ruminants: Sheep versus goats. HELMIN., 48(3): 137-144.

35. Kupčisnkas, T., Stadaliene, I., Šolmskas, A., Trusevičius, P., Varady, M. and Petkevičus, S. (2016) Worm control practices and prevalence of anthelmintic resistance using in vivo FECRTs on smallholder sheep farms in Lithuania. HELMIN, 53(1): 24-30.

36. Gilleard, J. (2006) Understanding anthelmintic resistance: The need for genomics and genetics. Int. J. Parasit., 36(12): 1227-1239.

37. Alvarez-Sanchez, M.A., Mainar-Laime, R.C., PerezGarrcia, J., Monteadudo-Rodriguez, M., Martin-Gomez, S. and Rojo-Vazquez, F.A. (2001) Antihelmintic Resistence in Small Ruminant Flocks in Spain: Extension in the Leon Province (NW). In the Abstract to the $18^{\text {th }}$ International Conference of the World Association for the Advancement of Veterinary Parasitology, August 26-30, Stresa, Italy. p155.

38. Traversa, D., Paoletti, B., Otranto, D. and Miller, J. (2007) First report of multiple drug resistance in Trichostrongylus affecting sheep under field conditions in Italy. Parasitol. Res., 101(6): 1713-1716.

39. Borgsteede, F.H.M., Dercksen, D.D. and Huijbers, R. (2007) Doramectin and albendazole resistance in sheep in The Netherlands. Vet. Parasitol., 144(1-2): 180-183.

40. Bjørn, H., Monrad, J. and Nansen, P. (1991) Anthelmintic resistance in nematode parasites of sheep in Denmark with special emphasis on levamisole resistance in Ostertagia circumcincta. Acta Vet. Scand., 32(2): 145-154.

41. Maingi, N., Bjørn, H., Thamsborg, S.M., Bøgh, H.O. and Nansen, P. (1997) Anthelmintic resistance in nematode parasites of sheep in Denmark. Small Rumin. Res., 23(2-3): 171-181.

42. Calvete, C., Calavia, R., Ferrer, L.M., Ramos, J.J., Lacasta, D. and Uriarte, J. (2012) Management and environmental factors related to benzimidazole resistance in sheep nematodes in Northeast Spain. Vet. Parasitol., 184(2-4): 193-203.

43. Kaplan, R.M. (2004) Drug resistance in nematodes of veterinary importance: A status report. Trends Parasitol., 20(10): $477-481$
44. Voigt, K., Scheuerle, M. and Hamel, D. (2012) Triple anthelmintic resistance in Trichostrongylus spp. in a German sheep flock. Small Rumin. Res., 106: 30-32.

45. Anupöld, A.M., Hinney, B. and Joachim, A. (2014) The resistance status of gastrointestinal strongyles against anthelmintics in three Estonian sheep flocks. Berl. Munch. Tierarztl. Wochenschr., 127(1-2): 50-55.

46. Sile, I., Romane, E., Reinsone, S., Maurina, B., Tirzite, D. and Dambrova, M. (2020) Data on medicinal plants in the records of Latvian folk medicine from the $19^{\text {th }}$ century. Data Brief., 28: 105024.

47. Sile, I., Romane, E., Reinsone, S., Maurina, B., Tirzite, D. and Dambrova, M. (2020) Medical plants and their uses recorded in the archives of Latvian folklore from the $19^{\text {th }}$ century. J. Ethnopharmacol., 249: 112378.

48. Mayer, M., Vogl, R.C., Amorena, M., Hamburger, M. and Walkenhorst, M. (2014) Treatment of organic livestock with medical plants: A systematic review of European ethnoveterinary research. Forsch. Komplementmed., 21(6): 375-386.

49. Pharmaceutical Society of Great Britain. (1970) British Veterinary Codex. Department of Pharmaceutical Sciences Pharmaceutical Press. p317.

50. Farnsworth, N.R., Akerele, O., Bingel, A.S., Soejarto, D.D. and Guo, Z. (1985) Medicinal plants in therapy. Bull. World Health Organ., 63(6): 965-981.

51. Malla, B., Gauchan, D.P. and Chhetri, R.B. (2015) An ethnobotanical study of medicinal plants used by ethnic people in Parbat district of Western Nepal. J. Ethnopharmacol., 165: 103-117.

52. Hossen, M.J., Uddin, M.B., Sayeem, S., Ahmed, U., Yu, Z.L. and Cho, J.Y. (2016) Traditional medicine/plants for the treatment of reproductive disorders in Asia Nations. Pak. Vet. J., 36(2): 127-133.

53. Jia, W., Gao, W. and Tang, L. (2003) Antidiabetic herbal drugs officially approved in China. Phytother. Res., 17(10): 1127-1134.

54. Athanasiadou, S., Githiori, J. and Kyriazakis, I. (2007) Medicinal plants for helminth parasite control: Facts and fiction. Animal, 1(9): 1392-1400.

55. Githiori, B.J., Athanasiadou, S. and Thamsborg, M.S. (2006) Use of plants in novel approaches for control of gastrointestinal helminths in livestock with emphasis on small ruminants. Vet. Parasitol., 139(4): 308-320.

56. Fomum, W.S. and Nsahlai, V.I. (2017) In vitro evaluation of anthelmintic efficacy of some plant species possessing proteinases and/or other nitrogenous compounds in small ruminants. J. Altern. Complement. Med., 3(3): 38.

57. Beigh, A.Y. and Ganai, M.A. (2017) Potential of wormwood (Artemisia absinthium Linn.) herb for use as an additive in livestock feeding: A review. J. Pharm. Innov., 6(8): 176-187.

58. Tariq, A.K. and Tantry, A.M. (2012) Preliminary studies on plants with anthelmintic properties in Kashmir the NorthWest temperate Himalayan region of India. Chin. Med., 3(2): 106-112.

59. Waller, J.P., Bernes, G., Thamsborg, M.S., Sukura, A., Richter, H.S., Ingebrigtsen, K. and Höglund J. (2001) Plants as deworming agents of livestock in the Nordic countries: Historical perspective, popular beliefs and prospects for the future. Acta Vet. Scand., 42(1): 31-44.

60. Zeineldin, M., Abdelmegeid, M., Barakat, R. and Ghanem, M. (2018) A review: Herbal medicine as an effective therapeutic approach for treating digestive disorders in small ruminants. Alex. J. Vet. Sci., 56(1): 33-44.

61. Rajeswari, D.V. (2014) Anthelmintic activity of plants: A review. Res. J. Phytochem., 8(3): 57-63.

62. Laudato, M. and Capasso, R. (2013) Useful plants for animal therapy. OA Altern. Med., 1(1): 1-6.

63. Lans, C., Turner, N., Khan, T., Brauer, G. and Boepple, W. (2007) Ethnoveterinary medicines used for ruminants in British Columbia, Canada. J. Ethnobiol. Ethnomed., 3(11): 1-22. 
64. Urban, J., Kokoska, L., Langrova, I. and Matejkova, J. (2008) In vitro anthelmintic effects of medicinal plants used in the Czech Republic. Pharm. Biol., 46(10-11): 808-813.

65. Dib, I., Angenot, L., Mihamou, A., Ziyyat, A. and Tits, M. (2017) Artemisia campestris L.: Ethnomedical, phytochemical and pharmacological review. J. Herb. Med., 7(Mar.): $1-10$.

66. Abo-EL-Sooud, K. (2018) Ethnoveterinary perspectives and promising future. Int. J. Vet. Sci. Med., 6(1): 1-7.

67. Sandoval-Castro, A.C., Torres-Acosta, J.F.J., Hoste, H., Salem, M.Z.A. and Chan-Perez, I.J. (2012) Using plant bioactive materials to control gastrointestinal tract helminths in livestock. Anim. Feed Sci. Technol., 176(1-4): 192-201.

68. Hammond, A.J., Fielding, D. and Bishop, C.S. (1997) Prospects for plant anthelmintics in tropical veterinary medicine. Vet. Res. Commun., 21(3): 213-228.

69. Bauri, K.R., Tigga, N.M. and Kullu, S.S. (2015) A review on the use of medicinal plants to control parasites. Indian $J$. Nat. Prod. Resour., 6(4): 268-277.

70. Bartha, G.S., Quave, L.C., Balogh, L. and Papp, N. (2015) Ethnoveterinary practices of Covasna County, Transylvania, Romania. J. Ethnobiol. Ethnomed., 11(35): 1-22.

71. Viegi, L., Pieroni, A., Guarrera, M.P. and Vangelisti, R. (2003) A review of plants used in folk veterinary medicine in Italy as the basis for a databank. J. Ethnopharmacol., 89(2-3): 221-244.

72. Pye, C.R., Bertin, M.J., Lokey, R.S., Gerwick, W.H. and Linington, R.G. (2017) Retrospective analysis of natural products provides insights for future discovery trends. Proc. Natl. Acad. Sci. U. S. A., 114(22): 5601-5606.

73. Chitra, J., Khatana, S. and Vijayvergia, R. (2019) Bioactivity of secondary metabolites of various plants: A review. Int. J. Pharm. Sci. Res., 10(2): 494-504.

74. Anand, U., Jacobo-Herrera, N., Altemimi, A. and Lakhssassi, N. (2019) A comprehensive review on medicinal plants as antimicrobial therapeutics: Potential avenues of biocompatible drug discovery. Metabolites, 9(11): 1-13.

75. Kumar, S. and Pandey, A.K. (2013) Chemistry and biological activities of flavonoids: An overview. Sci. World J., 2013: 162750

76. Hassan, R., Mohammad, H.F. and Reza, K. (2017) Polyphenols and their benefits: A review. Int. J. Food Properties, 20(2): 1700-1741.

77. Pandey, K.B. and Rizvi, S.I. (2009) Plant polyphenols as dietary antioxidants in human health and disease. Oxid. Med. Cell. Longev., 2(5): 270-278.

78. Kardel, M., Taube, F., Schulz, H., Schütze, W. and Gierus, M. (2013) Different approaches to evaluate tannin content and structure of selected plant extracts review and new aspects. J. Appl. Bot. Food Qual., 86(1): 154-166.

79. de Almeida, C.A.A., de-Faria, F.M., Dunder, R.J., Manzo, P.L.B., Souza-Brito, R.A.M. and Luiz-Ferreira, A. (2017) Recent trends in pharmacological activity of alkaloids in animal colitis: Potential use for inflammatory bowel disease. Evid. Based Complement. Alternat. Med., 2017: 8528210.

80. Verpoorte, R. (2005) Alkaloids. In: Worsfold, P., Townshend, A., Poole, C., editors. Encyclopedia of Analytical Science. $2^{\text {nd }}$ ed. Elsevier, Amsterdam, Netherlands. p56-61.

81. Khanbabaee, K. and Van Ree, T. (2001) Tannins: Classification and definition. Nat. Prod. Rep., 18(6): 641-649.

82. Verpoorte, R. (2005) Alkaloids. In: Worsfold, P., Townshend, A., Poole, C., editors. Encyclopedia of Analytical Science. $2^{\text {nd }}$ ed. Elsevier, Amsterdam, Netherlands. p56-61.

83. Debnath, B., Singh, W.S., Das, M., Goswami, S., Singh, K.M., Maiti, D.D. and Manna, K. (2018) Role of plant alkaloids on human health: A review of biological activities. Mater. Today Chem., 9(Sept.):56-72.

84. Lin, X.S., Curtis, A.M. and Sperry, J. (2020) Pyridine alkaloids with activity in the central nervous system. Bioorg. Med. Chem., 28(24): 1-22.

85. Morsy, N.F.S. (2017) Chemical Structure, Quality Indices and Bioactivity of Essential Oil Constituents, Active Ingredients from Aromatic and Medicinal Plants, Hany A. El-Shemy, IntechOpen, London. Available from: https:// www.intechopen.com/books/active-ingredients-from-aromatic-and-medicinal-plants/chemical-structure-quality-indices-and-bioactivity-of-essential-oil-constituents Retrieved on 23.04.2021.

86. Vintilă, I. (2017) Basic structure, nomenclature, classification and properties of organic compounds of essential oil. In: Essential Oils in Food Processing. John Wiley and Sons, New York. p173-190.

87. Raut, S.J. and Karuppayil, M.S. (2014) A status review on the medicinal properties of essential oils. Ind. Crops Prod., 62(1): 250-264.

88. Sharifi-Rad, J., Sureda, A., Tenore, G.C., Daglia, M., Sharifi-Rad, M., Valussi, M., Tundis, R., SharifiRad, M., Loizzo, M.R., Ademiluyi, A.O., Sharifi-Rad, R., Ayatollahi, S.A. and Iriti, M. (2017) Biological activities of essential oils: From plant chemoecology to traditional healing systems. Molecules, 22(1): 1-55.

89. Orchard, A. and Van Vuuren, S. (2017) Commercial essential oils as potential antimicrobials to treat skin diseases. Evid. Based Complement. Alternat. Med., 2017: 4517971.

90. Coté, H., Boucher, M.A., Pichette, A. and Legault, J. (2017) Anti-Inflammatory, antioxidant, antibiotic, and cytotoxic activities of Tanacetum vulgare L. essential oil and its constituents. Medicines, 4(2): 1-34.

91. Acharya, J., Hildreth, B.M. and Reese, N.R. (2014) In vitro screening of forty medical plant extracts from the United States Northern Great Plains for anthelmintic activity against Haemonchus contortus. Vet. Parasitol., 201(1-2): 75-81.

92. Collin, J.G., Deslauriers, I., Pageau, N. and Gtrgnon, M. (1992) Essential oil of tansy (Tanacetum vulgare L.) of Canadian origin. J. Essent. Oil Res., 5(6): 629-638.

93. Magierowicz, K., Górska-Drabik, E. and Sempruch, C. (2020) The effect of Tanacetum vulgare essential oil and its main components on some ecological and physiological parameters of Acrobasis advenella (Zinck.) (Lepidoptera: Pyralidae). Pestic. Biochem. Physiol., 162(Jan): 105-112.

94. Keskitalo, M., Pehu, E. and Simon, J.E. (2001) Variation in volatile compounds from tansy (Tanacetum vulgare $L$.) related to genetic and morphological differences of genotypes. Biochem. Syst. Ecol., 29(3): 267-285.

95. Vaverková, S., Mikulásová, M., Habán, M. and Sloboda, P. (2006) Studium kvalitatívnych vlastností silice Tanacetum vulgare L. [A study of qualitative properties of the essential oil of Tanacetum vulgare L]. Ceska Slov. Farm., 55(4): 181-185.

96. Chiasson, H., Bélanger, A., Bostanian, N., Vincent, C. and Poliquin, A. (2001) Acaricidal properties of Artemisia absinthium and Tanacetum vulgare (Asteraceae) essential oils obtained by three methods of extraction. J. Econ. Entomol., 94(1): 167-171.

97. Rohloff, J., Mordal, R. and Dragland, S. (2004) Chemotypical variation of tansy (Tanacetum vulgare L.) from 40 different locations in Norway. J. Agric. Food Chem., 52(6): 1742-1748.

98. Mockute, D. and Judzentiene, A. (2004) Composition of the essential oils of Tanacetum vulgare L. growing wild in Vilnius district (Lithuania). J. Essent. Oil Res., 16(6): 550-553.

99. Pålsson, K., Jaenson, T.G.T., Bæckström, P. and BorgKarlson, K.A. (2008) Tick repellent substances in the essential oil of Tanacetum vulgare. J. Med. Entomol., 45(1): 4588-4593.

100. Duke, J.A. 2001. Handbook of Phytochemical Constituents of GRAS Herbs and Other Economic Plants. CRC Press, Boca Raton, FL. p676. 
101. Muresan, M., Benedec, D., Vlase, L., Oprean, R., Toiu, A. and Oniga, I. (2015) Screening of polyphenolic compounds, antioxidant and antimicrobial properties of Tanacetum vulgare from Transylvania. Chemia, 60(1): 127-138.

102. Stojković, B.M., Mitić, S.S., Pavlović, J.L., Stojanović, B.T. and Paunović, D.Đ. (2017) Antioxidant potential of Tanacetum vulgare L. extracts. Biol. Nyssana, 5(1): 47-51.

103. Kumar, S.G., Venkataramaiah, C. and Rajendra, W. (2018) Qualitative and quantitative phytochemical profile and in vitro antioxidant activity of methanolic extract of Artemisia vulgaris. J. Pharm. Innov., 7(9): 348-354.

104. Abiri, R., Silva, A.L.M., de Mesquita, L.S.S., de Mesquita, J.W.C., Atabaki, N., de Almeida, E.B. Jr., Shaharuddin, N.A. and Malik, S. (2018) Towards a better understanding of Artemisia vulgaris: Botany, phytochemistry, pharmacological and biotechnological potential. Food Res. Int., 109(Jul): 403-415.

105. Soon, L., Ng, P.Q., Chellian, J., Madheswaran, T., Panneerselvam, J., Gupta, G., Nammi, S., Hansbro, N.G., Hsu, A., Dureja, H., Mehta, M., Satija, S., Hansbro, P.M., Dua, K., Collet, T. and Chellappan, D.K. (2019) Therapeutic potential of Artemisia vulgaris: An insight into underlying immunological mechanisms. J. Environ. Pathol. Toxicol. Oncol., 38(3): 205-216.

106. Katerere, R.D. and Luseba, D. (2010) Ethnoveterinary Botanical Medicine Herbal Medicine for Animal Health. CPC Press, Boca-Raton. p423.

107. Judzentiene, A. and Budiene, J. (2018) Chemical polymorphism of essential oils of Artemisia vulgaris growing wild in Lithuania. Chem. Biodivers., 15(2): 1-13.

108. Lutgen, P. (2018) Tannins in artemisia: The hidden treasure of prophylaxis. J. Pharm. Innov., 6(3): 176-181.

109. Seca, A. and Pinto, D. (2019) Biological potential and medical use of secondary metabolites. Medicines, 6(2): 1-66.

110. Blagojević, P., Radulović, N., Palić, R. and Stojanović, G. (2006) Chemical composition of the essential oils of Serbian wild-growing Artemisia absinthium and Artemisia vulgaris. J. Agric. Food Chem., 54(13): 4780-4789.

111. Pandey, P.B., Thapa, R. and Upreti, A. (2017) Chemical composition, antioxidant and antibacterial activities of essential oil and methanol extract of Artemisia vulgaris and Gaultheria fragrantissima collected from Nepal. Asian Pac. J. Trop. Dis., 10(10): 952-959.

112. Ashok, P.K. and Upadhyaya, K. (2013) Preliminary phytochemical screening and physicochemical parameters of Artemisia absinthium and Artemisia annua. J. Pharmacogn. Phytochem., 1(6): 229-235.

113. Pires, J.M., Mendes, F.R., Negri, G., Duarte-Almeida, J.M. and Carlini, E.A. (2009) Antinociceptive peripheral effect of Achillea millefolium L. and Artemisia vulgaris L.: Both plants known popularly by brand names of analgesic drugs. Phytother. Res., 23(2): 212-219.

114. Moacă, E.A., Pavel, I.Z., Danciu, C., Crăiniceanu, Z., Minda, D., Ardelean, F., Antal, D.S., Ghiulai, R., Cioca, A., Derban, M., Simu, S., Chioibaş, R., Szuhanek, C., and Dehelean, C.A. (2019) Romanian wormwood (Artemisia absinthium L.): Physicochemical and nutraceutical screening. Molecules, 24(17): 1-21.

115. Mravčáková, D., Komáromyová, M., Babják, M., Dolinská, M.U., Königová, A., Petrič, D., Čobanová, K., Ślusarczyk, S., Cieslak, A., Várady, M. and Váradyová, A. (2020) Anthelmintic activity of wormwood (Artemisia absinthium L.) and Mallow (Malva sylvestris L.) against Haemonchus contortus in Sheep. Animals, 10(2): 1-14.

116. Wormwood. (2013) Absinthe herba 04/2011:1380. European Pharmacopoeia. $8^{\text {th }}$ ed. Council of Europe, 67075 Strasbourg Cedex, France, p1424-1425.

117. Msaada, K., Salem, N., Bachrouch, O., Bousselmi, S., Tammar, S., Alfaify, A., Al Sane, K., Ben Ammar, W., Azeiz, S., Brahim, A.H., Hammami, M., Selmi, S., Limam, F. and Marzoul, B. (2015) Chemical composition and antioxidant and antimicrobial activities of wormwood (Artemisia absinthium L.) essential oils and phenolics. J. Chem.,Article ID 804658.

118. Moreno-Gonzalo, J., Manolaraki, F., Frutos, P., Hervas, G., Celaya, R., Osoro, K., Ortega-Mora, M.L., Hoste, H. and Ferre, I. (2013) In vitro effect of heather (Ericaceae) extracts on different development stages of Teledorsagia circumcincta and Haemonchus contortus. Vet. Parasitol., 197(1-2): 235-243.

119. Moreno-Gonzalo, J., Osoro, K., García, U., Frutos, P., Celaya, R., Ferreira, L.M.N., Ortega-Mora, L.N. and Ferre, I. (2014) Anthelmintic effect of heather in goats experimentally infected with Trichostrongylus colubriformis. Parasitol. Res., 113(2): 693-699.

120. Temraz, A.T. and El-Tantawy, W.H. (2008) Characterization of antioxidant activity of extract from Artemisia vulgaris. Pak. J. Pharm. Sci., 21(4): 321-326.

121. Singh, R., Verma, K.P. and Singh, G. (2012) Total phenolic, flavonoids and tannin contents in different extracts of Artemisia absinthium. J. Complement. Med. Res., 1(2): 101-104.

122. Chepel, V., Lisun, V. and Skrypnik, L. (2020) Changes in the content of some groups of phenolic compounds and biological activity of extracts of various parts of heather (Calluna vulgaris (L.) Hull) at different growth stages. Plants, 9(8): $1-19$.

123. González-Hernández, P.M., Karchesy, J. and Starkey, E.E. (2003) Research observation: Hydrolyzable and condensed tannins in plants of Northwest Spain forests. J. Range Manag., 56(5): 461-465.

124. Mandim, F., Barros, L., Calhelha, R.C., Abreu, R.M.V., Pinela, J., Alves, M.J., Heleno, S., Santos, P.F. and Ferreira, I.C.F. (2019) Calluna vulgaris (L.) Hull: Chemical characterization, evaluation of its bioactive properties and effect on the vaginal microbiota. Food Funct., 10(1): 78-89.

125. Rodrigues, F., Moreira, T., Pinto, D., Pimentel, B.F., Costa, G.S.A., Nunes, M.A., Albuquerque, T.G., Costa, S.H., Palmeira-de-Oliveira, A., Oliveira, I.A., Sut, S., Dall'Acqua, S. and Oliveira, P.P.B. (2018) The phytochemical and bioactivity profiles of wild Calluna vulgaris L. flowers. Food Res. Int., 111(Sept.): 724-731.

126. Deliorman-Orhan, D., Senol, S., Kartal, M. and Orhan, I. (2009) Assessment of antiradical potential of Calluna vulgaris (L.) Hull and its major flavonoid. J. Sci. Food Agric., 89(5): 809-814.

127. Vučić, D.M., Petković, M.R., Rodić-Grabovac, B.B., Stefanović, O.D., Vasić, S.M. and Comić, L.R. (2014) In vitro activity of heather [Calluna vulgaris (L.) Hull] extracts on selected urinary tract pathogens. Bosnian J. Basic Med. Sci., 14(4): 234-238.

128. Saaby, L., Rasmussen, H.B. and Jager, A.K. (2009) MAO-A inhibitory activity of quercetin from Calluna vulgaris (L.) Hull. J. Ethnopharmacol., 121(1): 178-181. 